Original Contribution

\title{
SUSTAINABLE INTENSIFICATION OF FOOD PRODUCTION
}

\author{
A. Heissenhuber ${ }^{1 *}$, E. Bloss ${ }^{1}$, C. Krämer ${ }^{2}$ \\ ${ }^{1}$ Chair of Agricultural Production and Resource Economics, Technische Universität München- \\ Weihenstephan, Freising, Germany \\ ${ }^{2}$ Projektbüro mareg (markt+region), Ippesheim, Germany
}

\begin{abstract}
The level of production intensity is influenced by the price of input factors and the price of output factors. If the price of output factors increases because of an increasing demand for agricultural products worldwide, the level of intensity - expressed as increasing use of means of production - will increase. This intensification can cause a lot of environmental damages like high values of nitrate in groundwater. Sustainable intensification means that realizing higher yields is possible without causing additional environmental damages. But most often there are interactions between an increasing intensity and the occurrence of environmental damages. Some examples for sustainable intensification are presented in the paper. To realize sustainability different political instruments can be used, like tightening of minimum requirements, more expensive inputs, e.g. in forms of nitrogen levy or prohibition of particular inputs, e.g. a pesticide and compensation payments for better protection of resources. But to decide which measures and instruments should be used it seems to be necessary to survey and evaluate the trade-offs between "intensification" and "sustainability".
\end{abstract}

Key Words: Intensity, natural resources, leakage effect, nutrient surplus, burden-sharing, polluter pays

\section{INTRODUCTION}

The term "Intensity" describes the production per unit, e.g. per land area or per animal. The addition of all the means of production is just admitted monetarily. Intensification characterizes the increase of means of production. The increase of input factors usually creates higher yields. The functional context of input and output (yield) is expressed by the production function. The aim of economic management isn't producing the highest possible yield but making highest possible profit, simplifying a maximized gap between input and output. This fact explains that USA's wheat yields are at about $3 \mathrm{t} /$ hectar and New Zealand's annual quantity of milk at about $5000 \mathrm{~kg} / \mathrm{cow}$ and year. It's obviously not worth striving for a higher level of yield even though it would be possible in these countries. Another situation is given in countries not having the necessary means of production and therefore don't achieve higher yield.

- The level of intensity, meaning the input, is influenced by the price of means of

\footnotetext{
*Correspondence to: Prof. Dr. Dr. h.c. Alois

Heissenhuber, Alte Akademie 14, 85354 Freising, phone: ++49-08161-713409, fax: ++49-08161-

713426,alois.heissenhuber@tum.de
}

production and the price of produced goods.

- The cheaper the means of production and the more expensive the produced goods are, the higher the intensity is.

- The level of intensity to be achieved from an economical point of view rises with increasing product prices.

If the product prices increase through a rising population and a growing demand for food, intensity will rise and intensification and land use changes take place (1-3). Indicated that a solely rising population doesn't automatically cause intensity, there also has to be a sufficient purchasing power. Simplifying the fact that almost one billion people are suffering from hunger does not contribute enhancing wheat yields in the US.

The level of intensity also depends on price/cost differentials. The resulting intensity can be indeed classified as not sustainable, outlining a not permanently possible economic activity. That's the case if natural resources are irreversibly damaged. Soil erosion could be mentioned as an example. Another example could be the excessive use of groundwater.

The term "sustainable intensification" means realizing higher yields "not just per hectare, 
but also per unit of non- renewable inputs and impacts upon ecosystem services" (1) and is also described by Godfray and Garnett (4). But this can only be accepted if natural resources can be used on a permanent basis. To ensure this form an economic point of view, the use of natural resources must be integrated to the operational cost accounting, either through monetary burden, e.g. taxes payments, or through prescribed limits of utilization leading in the end to an internalization of external costs.

\section{Key components for a sustainable intensification}

From an economic point of view optimal intensity is given by the highest possible difference between input and output. It can be assumed that more food and resources have to be provided in future. As far as appropriate economic incentives are ensured, intensification will follow. It's important to monitor that the intensification is sustainable, which means attention will be paid to the protection of natural resources (5-9) to ethical acceptability and finally to a sustainable consumption (Figure 1)

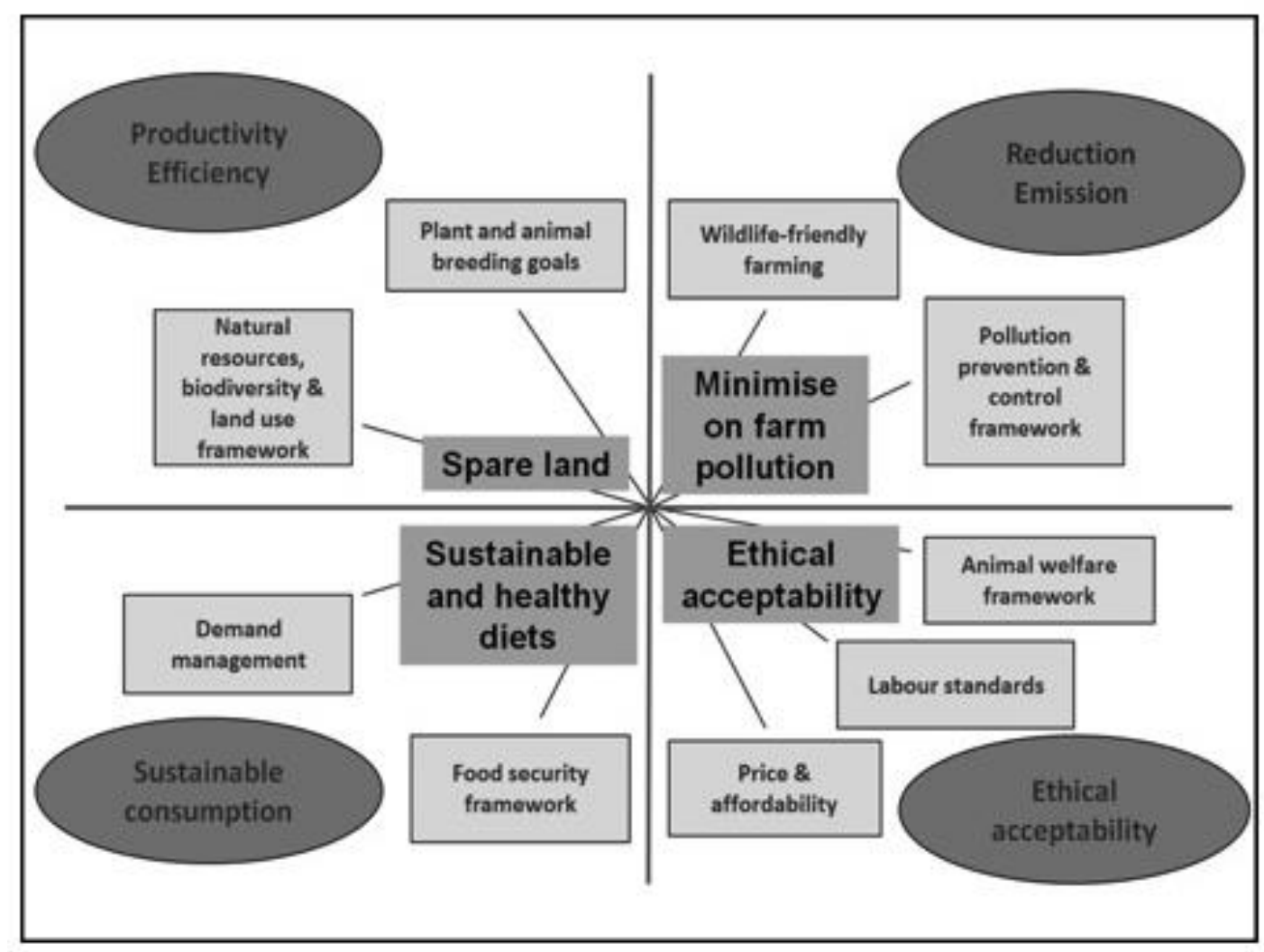

Figure 1. Sustainable Intensification (4)

In an initial approach it could be requested that single countries or rather regions take care of getting along with foods and resources produced on particular areas. This is entirely untrue in the general field of energy for Europe or Germany. Moreover it's not the case for protein rich feedingstuff. As Figure 2 shows, the net import of soybean - expressed in the unit of area - is 3,6 million ha in Germany alone (10).

This isn't to be criticized principally having an economy based on the division of labour. On one hand soybeans provide relatively high yields in other countries (e.g. Brazil) however production conditions for grain are comparably well in Europe. It should furthermore be mentioned that in countries like Brazil lots of farmland is available compared to the population. It speaks for itself, therefore, that Brazil became an important agricultural exporter. Indeed, a significant lower area segment per capita is given in Germany. High import volumes are as well related to the consumption level. In terms of a comprehensive consideration of the sustainable intensification the question arises if this high consumption level is appropriate. Moreover Germany uses almost 2 million ha farmland for renewable energies and renewable raw materials. This has to be challenged. 


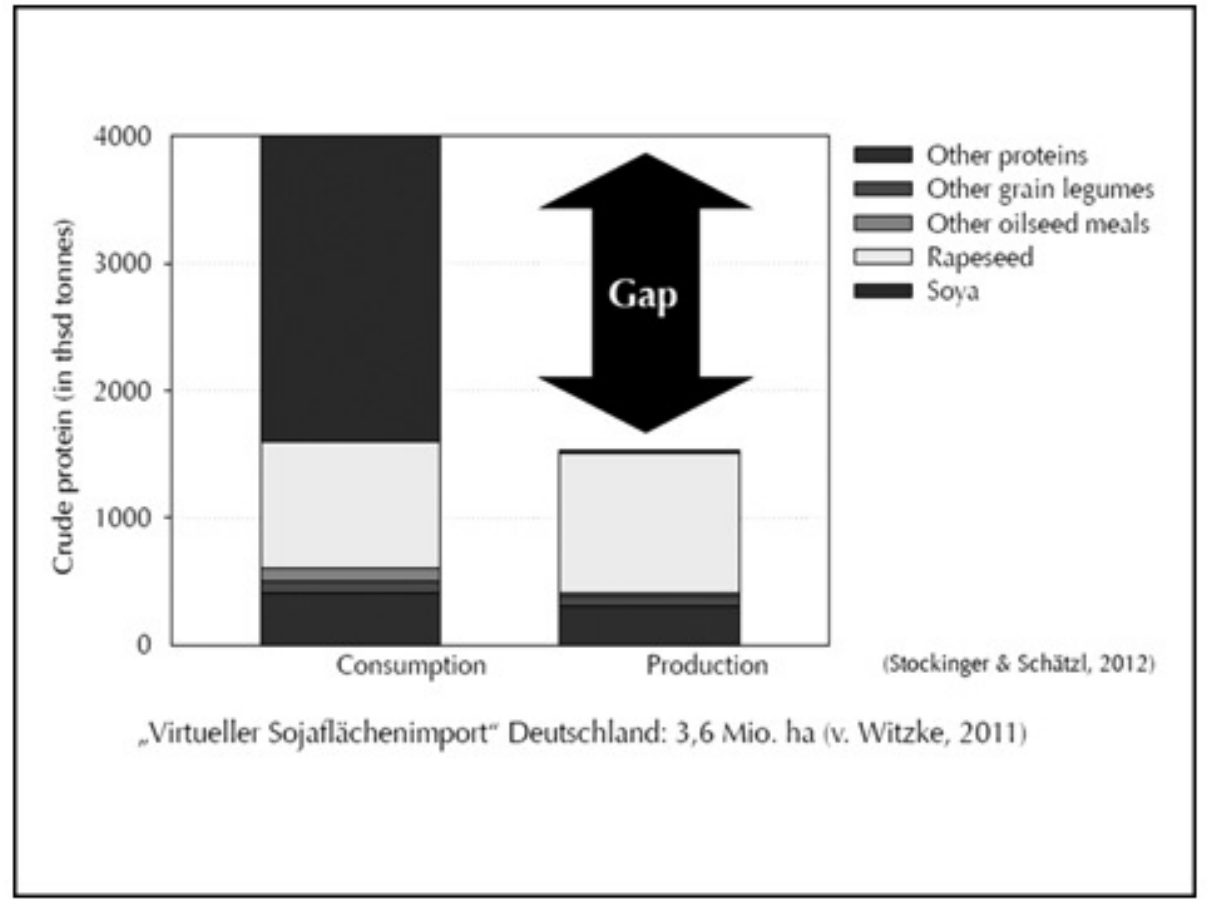

Figure 2. Soybean import in Germany (11)

In recent times efforts enhance to increase the domestic protein production. On one hand organic farms need non - genetically modified soybeans, on the other hand the import of soybeans ought to be diminished and thus the clearance of rain forest ought to be counteracted. Figure 3 shows that this goal is just ostensibly achieved.

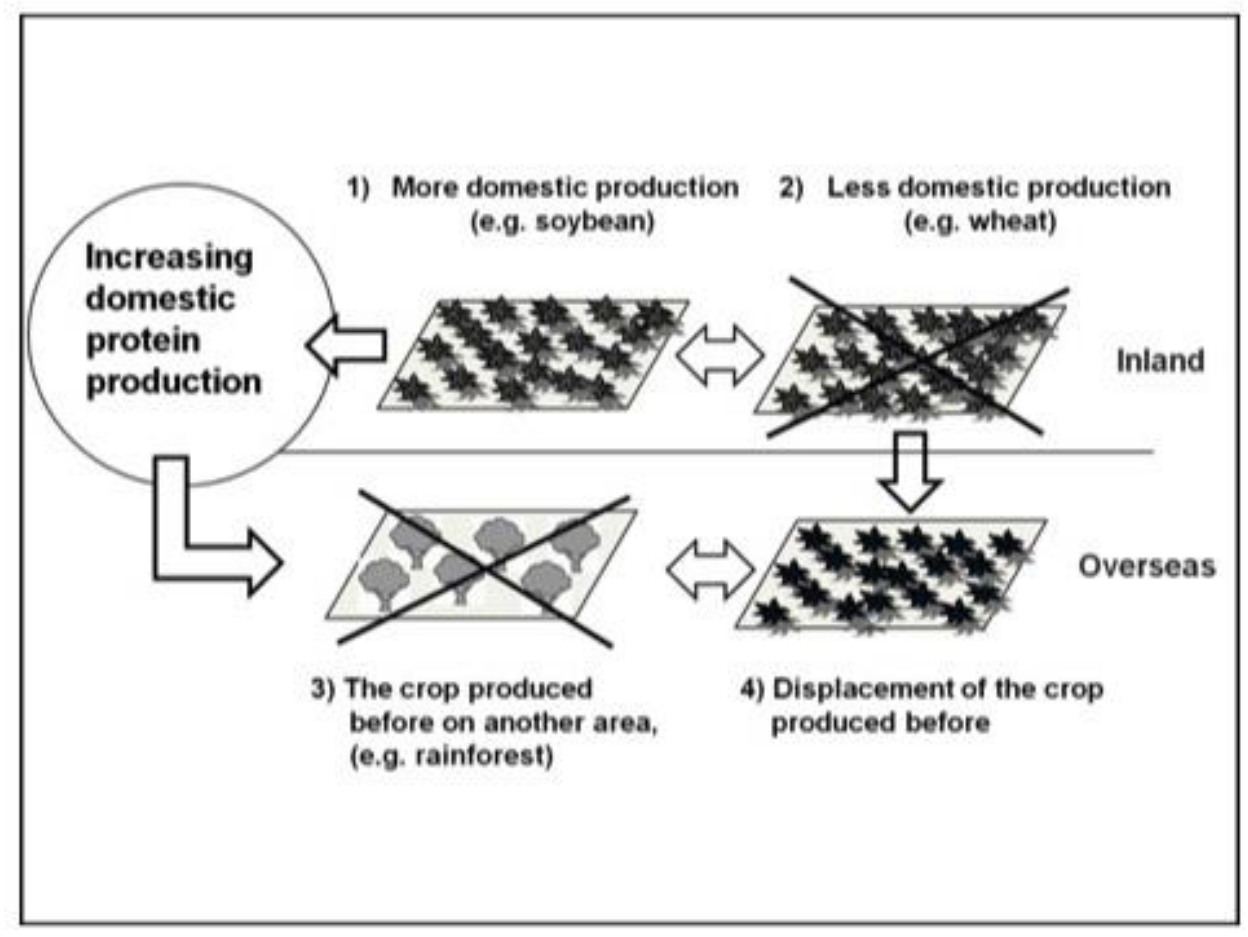

Figure 3. Goal of increasing domestic protein production (12)

The so-called "Leakage effect" occurs, relating solely to a shift. Although less protein is imported the import of grain is rising. Indeed this strategy is comprehensible, but it's no way to solve the named problem.

With the import of feedingstuff another problem comes along. Imported feedingstuff contains nutrients that leave the agricultural holding only to a small part, e.g. produced food like meat. In pig fattening, about $70 \%$ of the nitrogen contained in feedingstuff remains on the farm.

However, it is comprehensible that graft nurseries emerge high N-Surpluses (Figure 4) that may lead to rising nitrate levels in leachate. 


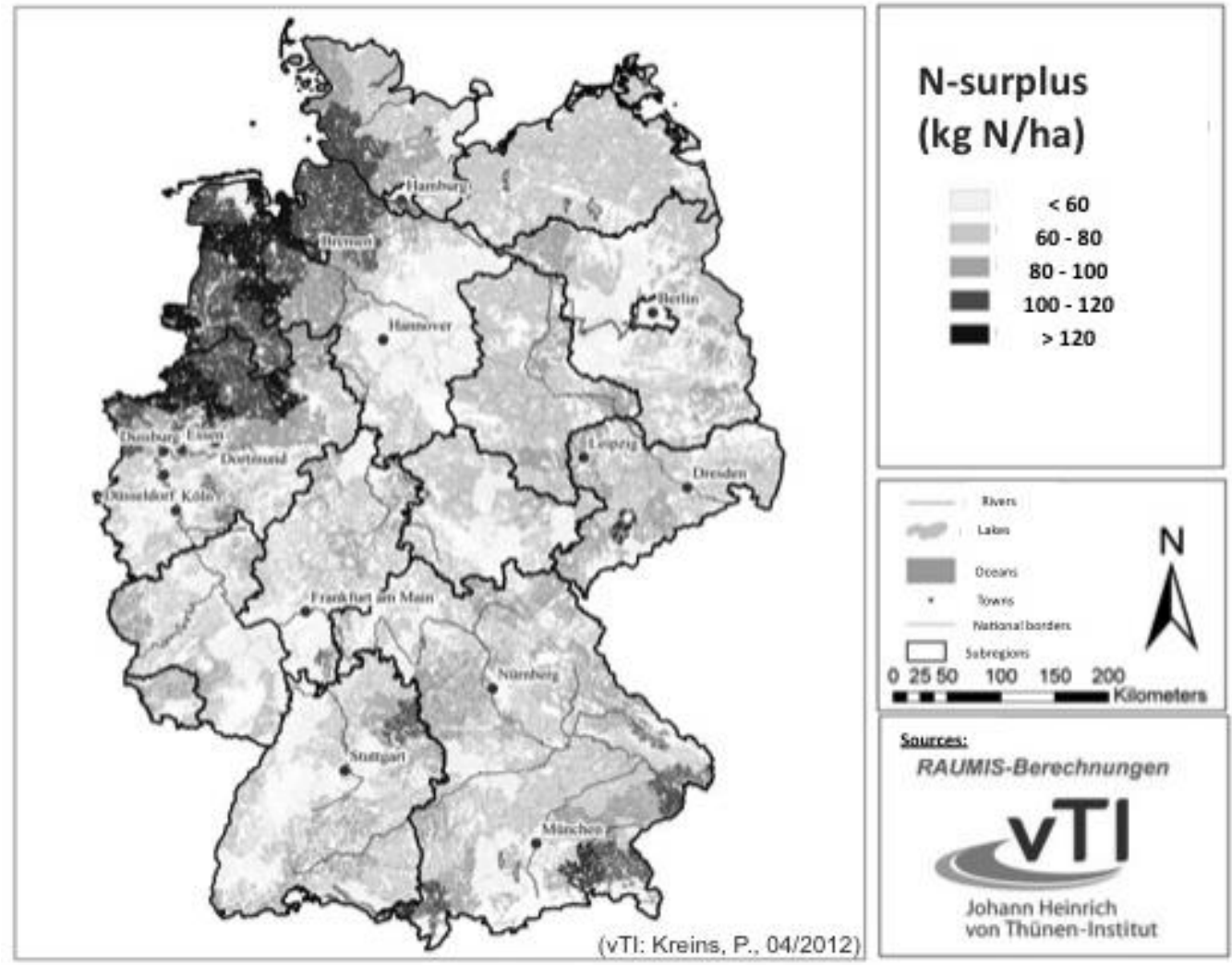

Figure 4. N-Surpluses in Germany (13)

Defaults of Fertilizer Regulation do obviously not appear to be consistently adhered to. This is because transport costs of liquid manure are relatively high, caused by high water contents (14).

This nutrient surplus not only appears in regions of high livestock density but also in urban regions through high food consumption.
So far nutrients are accumulated in sewage sludge, stored at landfills or incinerated. At the same time nutrients have to be obtained newly, Nitrogen from the air, phosphate from limited availability deposits. No recycling is taking place.

In the project "nutrient recycling" (Figure 5) nutrients are regionally returned.

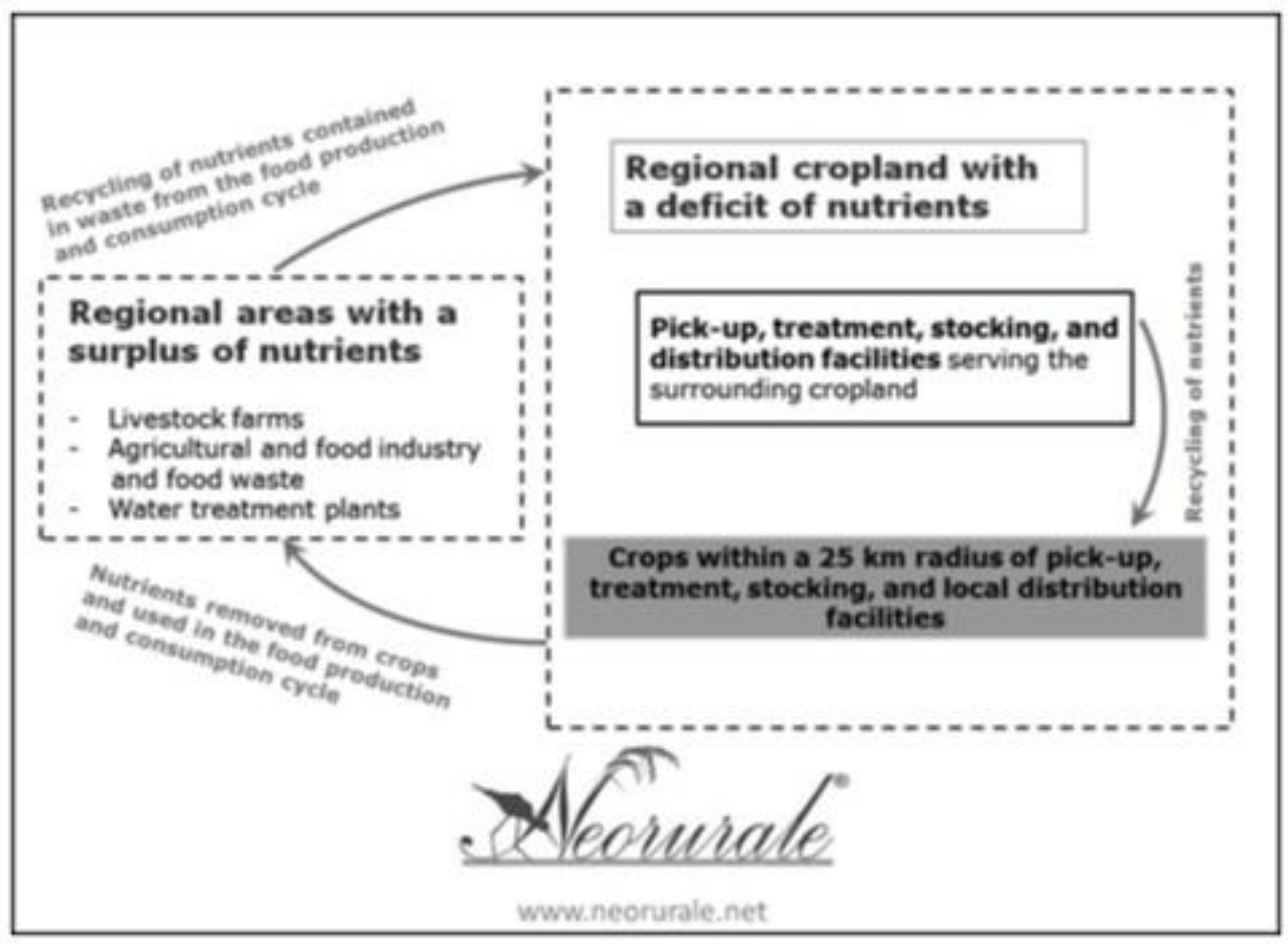

Figure 5. Project "nutrient recycling" (15)

Trakia Journal of Sciences, Vol. 13, № 3, 2015 
This recycling contributes emitting less greenhouse gasses (Figure 6).

\section{We can estimate the amount of GHGs avoided if the nutrients in digestates} completely displace mineral fertilizers:

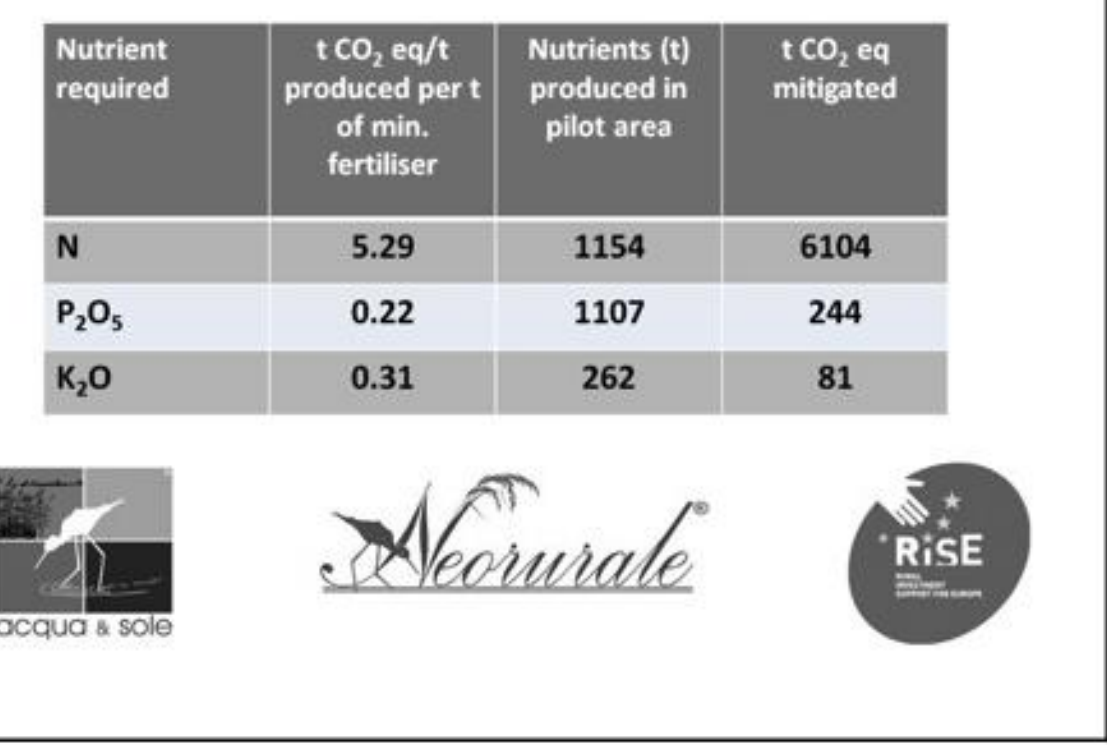

Figure 6. Project “nutrient recycling” (15)

The long-term goal has to be the consequent reuse of nutrient surpluses of livestock farming and urban areas.

\section{Strategies of realizing a sustainable intensification}

The level of means of production, the so called intensity level, first of all is the result of price/cost ratio. A particular extent of pressure on the resources, e.g. natural scenery and biodiversity, is the result. It has to be clarified under a socio-political point of view, to what extent a higher amount of protection of resources by the operators, e.g. farmers, is demanded without giving special support. Thus, it's about setting a level of "good agricultural practice" that ought to be complied by the "polluter pays" principle.

Furthermore, there is the possibility to realize a higher level of protection of resources by the "burden-sharing" principle (Figure 7).

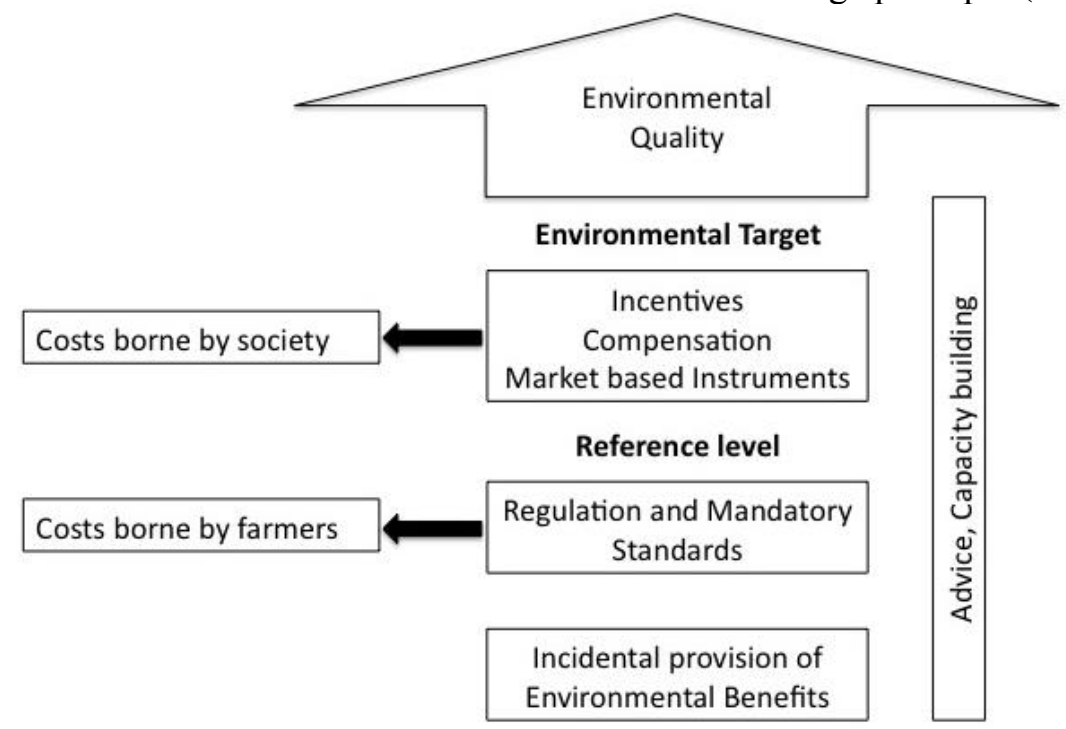

Figure 7. "Burden-sharing" principle (16)

In relation to the "polluter pays" principle, following approaches can be mentioned:

- Tightening of minimum requirements, e.g. tolerable nitrogen surpluses as part of the Fertilizer Regulation
This approach needs an appropriate control burden. Overstepping must be sanctioned.

- More expensive inputs, e.g. in forms of nitrogen levy or prohibition of particular inputs, e.g. a pesticide 
HEISSENHUBER A., et al.

In this case the protection of resources is realized by market mechanism. A sideeffect is the rising of production costs. As far as higher production costs can't be passed to the price this strategy will end up by a fall in incomes.

- Compensation payments for better protection of resources
This approach requires an appropriate indicator and regular control. It's for example already implemented in water protection areas. Nitrogen levels in soil are used as criterion. 2012th reference level was at 40,6 kg NO3/ha (Figure 8). Downward deviation leads to bonus, overstepping to malus.

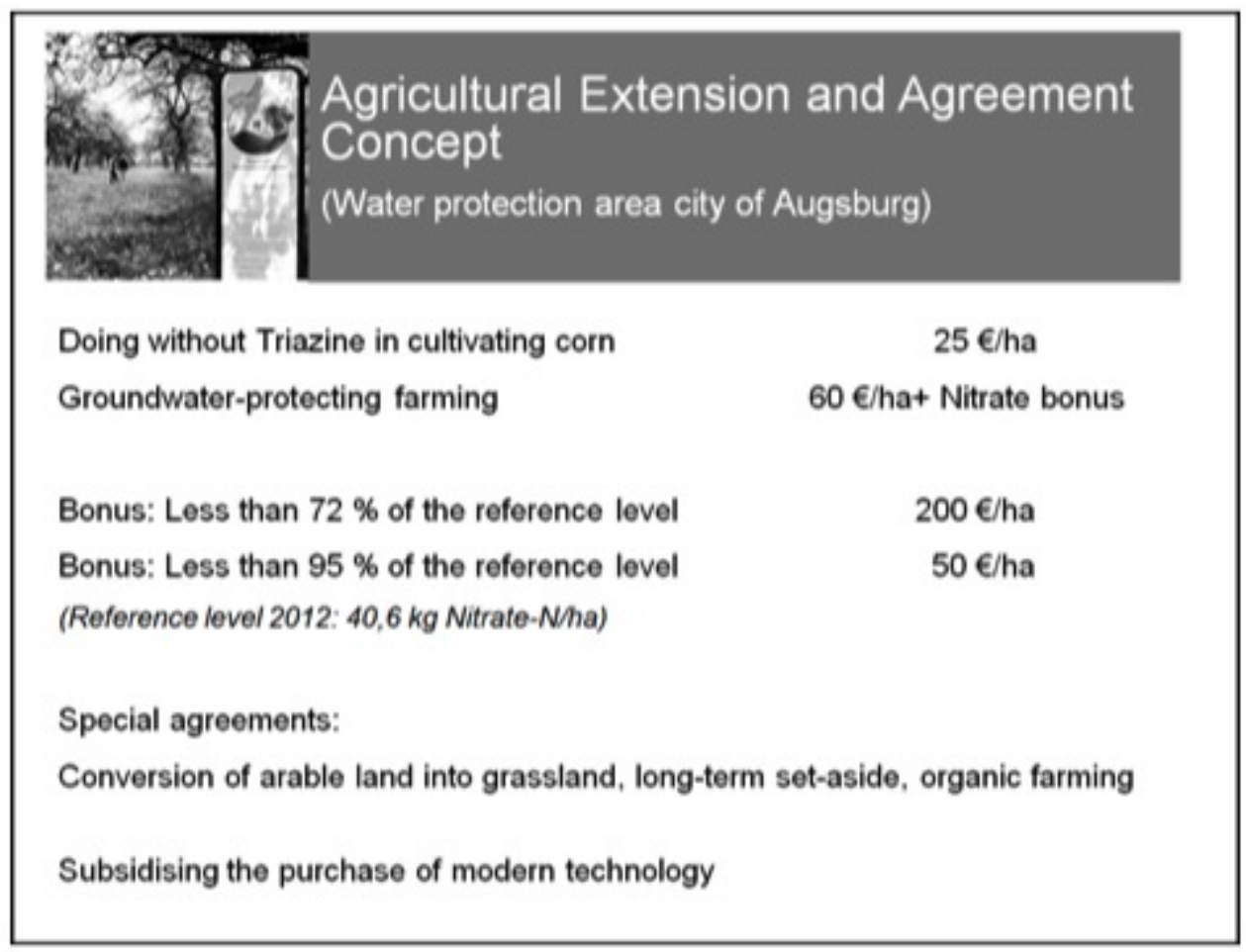

Figure 8. 2012th nitrate reference level (17)

Augsburg's public works department is able to show declining nitrogen levels in drinking water over the last few years (Figure 9).

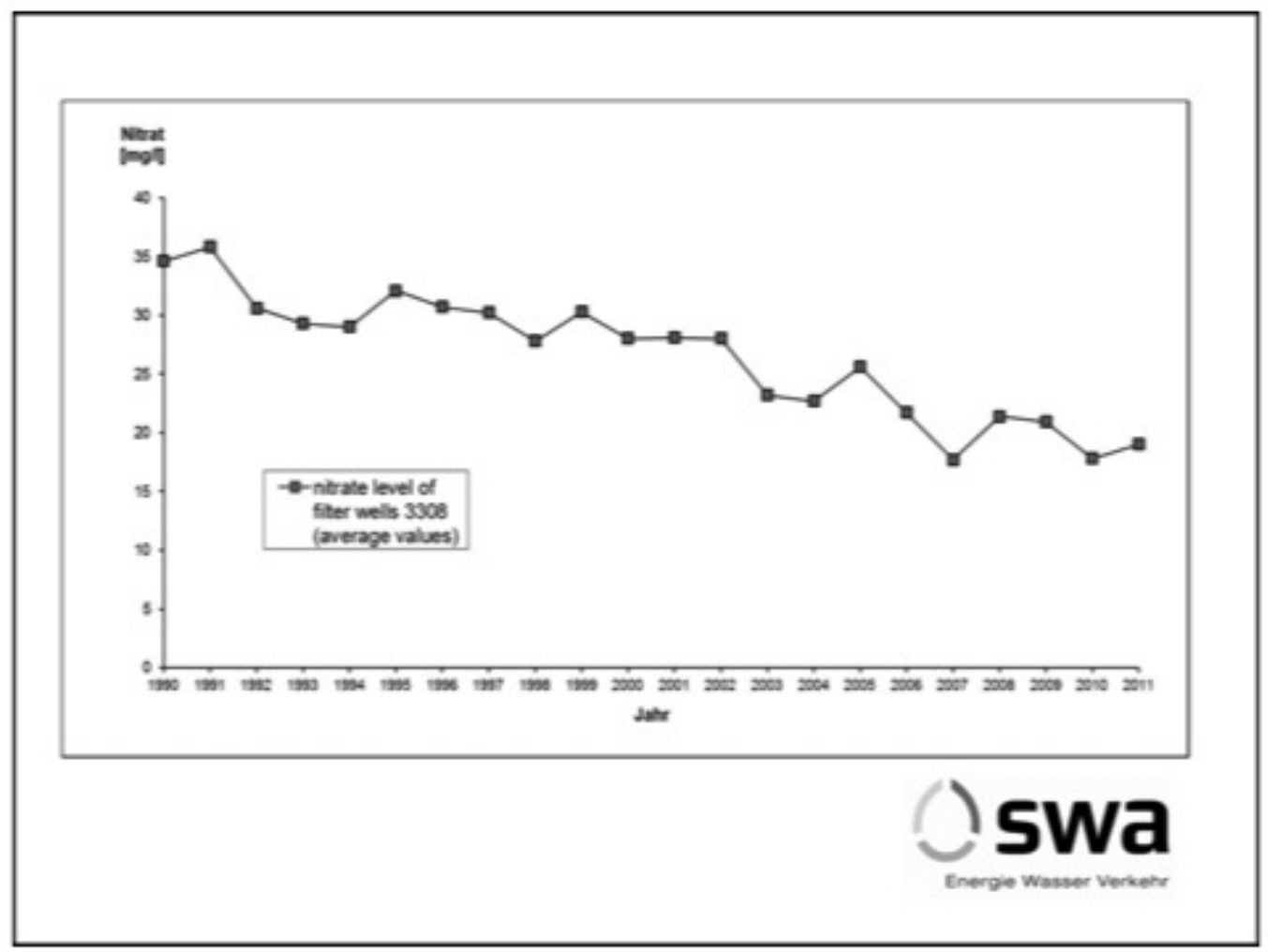

Figure 9. Declining nitrogen levels in drinking water (17)

Trakia Journal of Sciences, Vol. 13, № 3, 2015 
In conclusion a quite different strategy shall be presented. It's about education and consulting.
Figure 10 shows the result of a project from the CAU Bejjng.

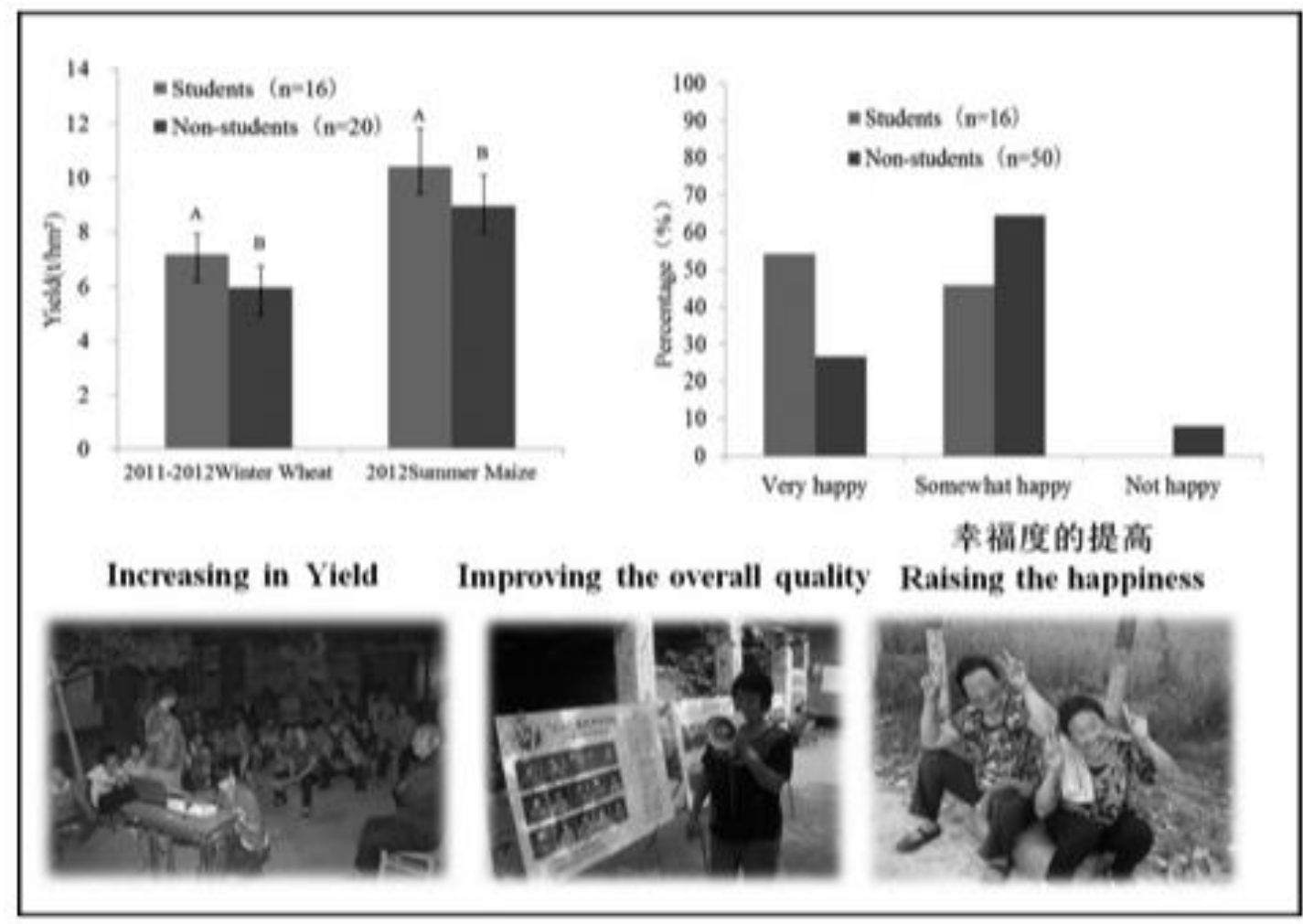

Figure 10. Project from CAU Bejjng (18)

In a side-project students succeeded an increasing yield through intensive consulting of the farmers. In another side-project the satisfaction and life quality in a village was enhanced.

\section{CONCLUSION}

With an increasing population worldwide and a change to more western diets as well as an increasing demand of land for growing renewable raw material there is the pressure of increasing the yield per input factor. This intensification may result in an increasing pressure on natural resources. A sustainable intensification is necessary to increase the yields without damaging the natural resources additional. Problems can be seen for example by importing lots of nutrients to Germany by feedingstuff. The high amount of nutrients can't be used in crop farming and therefore cause environmental damages e.g. in high nitrate surpluses in groundwater. There are some political options to address this problem, but every options does have side-effects as well as all technical solutions. So the sideeffects of measures and political instruments have to be surveyed and evaluated to come to an conclusion, which measures and instruments should be favoured.

\section{REFERENCES}

1. The Royal Society, Reaping the Benefits: Science and the Sustainable Intensification of Global Agriculture. London, The Royal Society, 2009.

2. Tilman, D. et al., Forecasting Agriculturally Driven Global Environmental Change. Science, 292: 281-284, 2001.

3. Godfray, H. C. J., et al., Food Security: The challenge of Feeding 9 Billion People. Science, 327: 812-818, 2010.

4. Garnett T. at al., Sustainable Intensification in Agriculture: Premises and Policies. Science, 341 (6141): 33-34, 2013.

5. Baldock, D., H. et al., The Environmental impacts of Irrigation in the European Union. London, Institute for European Environmental Policy, 2000.

6. Stoate, C. et al., Ecological Impacts of Arable Intensification. Journal of Environmental Management, 63: 337-365, 2001.

7. EEA, Progress Towards the European 2010 Biodiversity Target - Indicator Fact Sheets. Compendium to EEA Report No 4/2009, EEA Report No. 5/2009. Copenhagen, European Environment Agency. 2009a.

8. EEA, Water Resources Across Europe Confronting Water Scarcity and Drought. EEA Report / No 2/2009. Copenhagen, European Environment Agency. 2009b. 
HEISSENHUBER A., et al.

9. OECD, Environmental Performance of Agriculture Since 1990. OECD Publications, Paris, 2008.

10.v. Witzke, H. et al., Fleisch frisst Land. WWF Deutschland, Berlin, 2011.

11.Schätzl,R\&Stockinger,B.,Eiweißfuttermitte 1 im Überblick Versorgungsbilanzen, Potentiale und Wirtschaftlichkeit. Speech held on LfL-Praktikerforum 2012 Heimische Eiweißfuttermittel in der Schweine- und Geflügelhaltung Möglichkeiten und Grenzen. 1. Februar 2012 in Dettelbach. 2012

12.Heissenhuber, A., not published

13. Kreins, P., Nitrogen Surplus in different Region of Germany. von Thünen Institut, 2012.
14. Schieß1 et al., Aufbereitung und Transport von Wirtschaftsdünger. Umweltbundesamt, Dessau-Roßlau, 2015. In puplication process.

15.Potocnik,J.,NutrientrecyclingEnvironmental and agronomic benefits. Brussels $17^{\circ}$ July 2012.

16.IEEP, Provision of Public Goods through agriculture in the European Union, AGRI2008-EVAL-08, p. 145, 2008.

17.Sailer, E., SWA Augsburg

18.Zhou, S., Masterthesis, College of Resources and Environmental Sciences, China Agricultural University, Beijing 100193, China, 2013. 
HEISSENHUBER A., et al. 